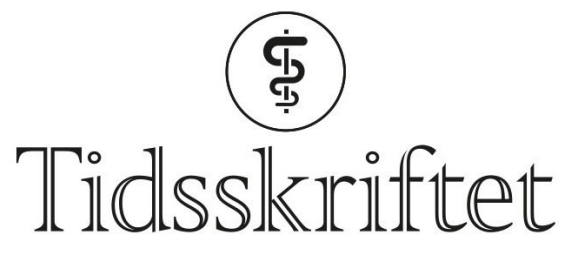

DEN NORSKE LEGEFORENING

\title{
Kunsten å prioritere
}

INTERVJU

JANNIKE REYMERT

E-post: jannike.reymert@gmail.com

Sosiologen Berit Bringedal har forsket på helsevesenet i 30 år. Hun mener at legene sier for lite nei. - Det er så mye man kunne sluttet med uten at det ville fått noen konsekvenser for folkehelsen.

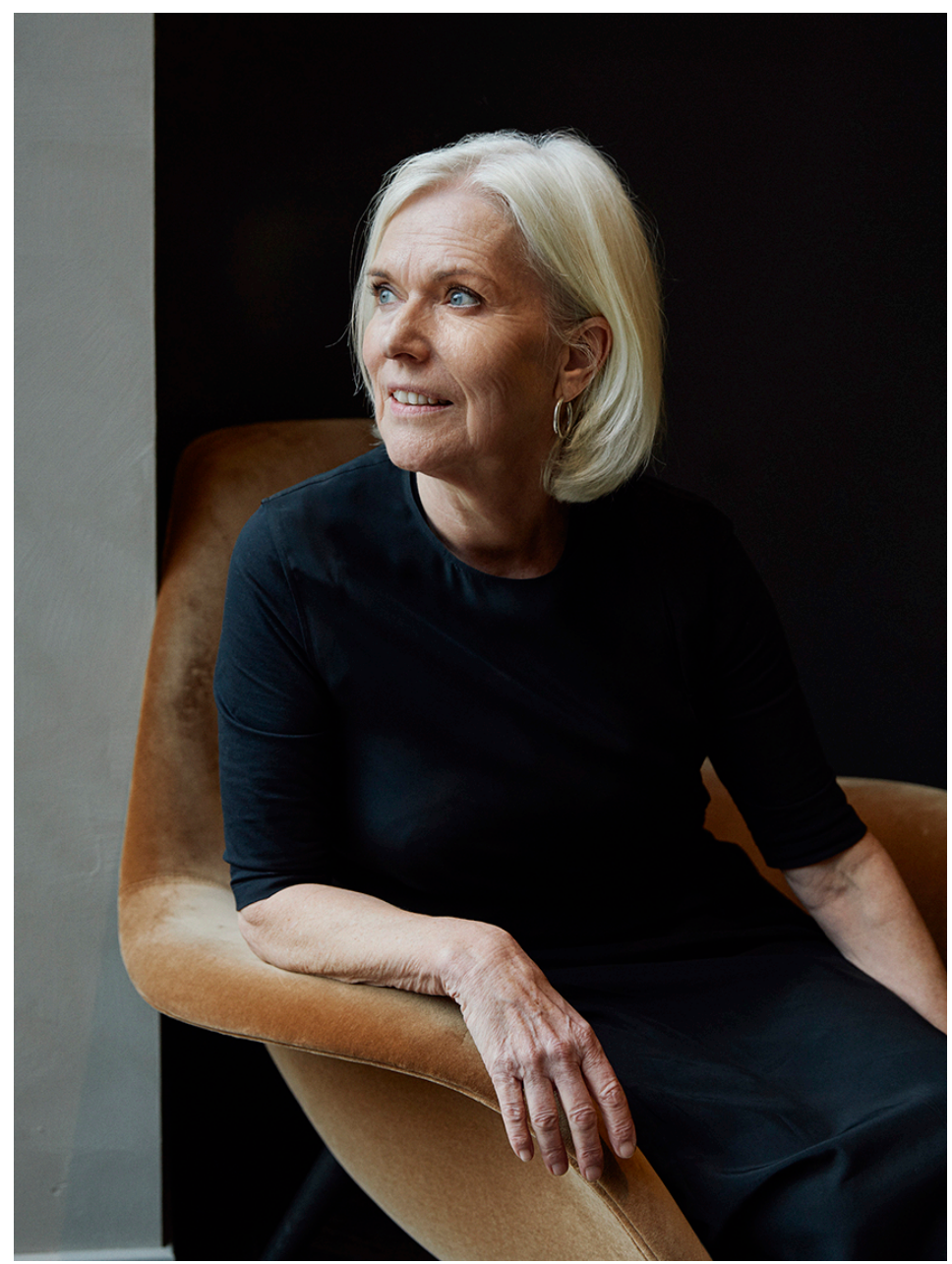

Foto: Birgit Solhaug

Hun har mye på hjertet. Et helt yrkesliv har hun forsket på helsevesenet, og nå i de siste årene spesifikt på norske leger. Samtalen er godt i gang før hun rekker å servere en kopp duftende, grønn te. 
- En trygg dialog er veldig viktig, men det legges ikke nok til rette for det. Man har så lett for å gå i skyttergravene!

Berit Bringedal snakker om styring av helsetjenesten og hvordan det påvirker det medisinske arbeidet. Selv jobber hun ved Legeforskningsinstituttet (LEFO)- finansiert av Sykehjelps- og pensjonsordningen for leger og av Legeforeningen. Oppdraget er å forske på leger i helsetjenesten, men ut over det har de stor frihet i forskningsvalg.

Fra sidelinjen sin i Legeforskningsinstituttet har hun lagt merke til at dialogen mellom politikere, helsebyråkrater, ledere og de ulike helseprofesjonene noen ganger bærer preg av mistillit.

- Mange leger opplever at de har for lite makt. At de som styrer helsetjenesten, ikke lytter nok til de som kjenner innholdet i virksomheten best. Alle parter har et ansvar for å snakke sammen uten fordommer.

Bringedal forklarer at dypest sett har alle det samme overordnede målet - å få et best mulig helsetilbud for pengene. Men i mange debatter mistenkeliggjøres motparten på en måte som direkte motarbeider dette.

- Men tror du det er mulig å endre det?

- Dette er en strukturell problemstilling. Mennesket deler fort omverdenen i «vi» og «de andre», og så tilskriver vi de andre uedle motiver. Dette tror jeg ikke vi kan endre, men det vi kan endre, er systemene.

\section{Mellom naturvitenskap og humaniora}

Som et eksempel trekker hun fram rapporteringskrav. Noen av dem kan oppleves som unødvendige - som skrivebordsprodukter som ikke treffer den kliniske virkeligheten godt nok. De blir dermed mer irriterende tidstyver enn hjelpemidler for bedre helsetjeneste.

- Legene kan ha god grunn til å stille spørsmål ved nytten av indikatorene. På den annen side har også styrerne god grunn til å pålegge legene å rapportere tilbake, sier hun.

\section{Berit Bringedal}

Født i 1956

Cand.mag., Universitetet i Bergen 1982

Mag.art., Universitetet i Oslo 1985

Dr.polit., Universitetet i Bergen 1997

Harkness-stipendiat, Harvard University og visiting scholar, Columbia University og

University of California

Sekretær, Rådet for prioritering i norsk helsetjeneste 2002-05

Seniorforsker, LEFO 2005-d.d.

Chair, Ethics Advisory Board of the Human Brain Project 2014-16 og 2019-20

Konstituert leder LEFO, høsten 2019

Seniorforsker, NORCE Research 2020-d.d.

- Utfordringen er å finne en god balanse mellom styring og kontroll på den ene siden og klinisk frihet og skjønnsutøvelse på den andre. Systemet hadde blitt mye bedre om de som står midt i den kliniske praksisen hadde blitt tatt mer med på råd. Da hadde de følt eierskap til tiltaket og vært mer åpne for å lete etter lure løsninger.

Diagnoser er ikke objektive sannheter, de skapes i møtet mellom pasient og lege

Gjennom årene har Bringedals forskning vist henne at de aller fleste legene er genuint opptatt av pasientene sine. Det som gir jobben mening, er å hjelpe pasientene til å få så god helse som mulig. 
- Det har jeg stor respekt for. Man kan si at medisin er et fag i skjæringsflaten mellom naturvitenskap og humaniora. Mange leger har funnet den gode balansen mellom de to. Selv om de fleste av oss er enige i at vitenskapelig evidens er viktig, er en klok skjønnsvurdering minst like viktig, slår hun fast.

- Det er å håpe at medisinen fortsetter slik at legene får utviklet og kombinert sin «kalde» og rasjonelle vurderingsevne med det humanistisk funderte skjønnet og den etiske bevisstheten om hva som er riktig og rettferdig. Dette krever god utdanning, så klart, men det krever også et helsevesen som er organisert og styrt slik at det bygger oppunder disse verdiene.

\section{Yrkesvalget}

At Bringedal ble sosiolog, er tilfeldig. Som ung student var hun åpen for det meste.

- Jeg ble inspirert til å velge sosiologi av forelesningene til Gudmund Hernes, som den gang var professor ved Universitetet i Bergen. Han fikk meg til å se at sosiologi ikke bare var en samling selvfølgeligheter, som jeg først hadde inntrykk av, men representerte et rikt tilfang av teori og empiri for å forstå dynamikken mellom mennesker og samfunn. Jeg ble særlig opptatt av kvantitative analyser og ville lage logiske modeller av det meste.

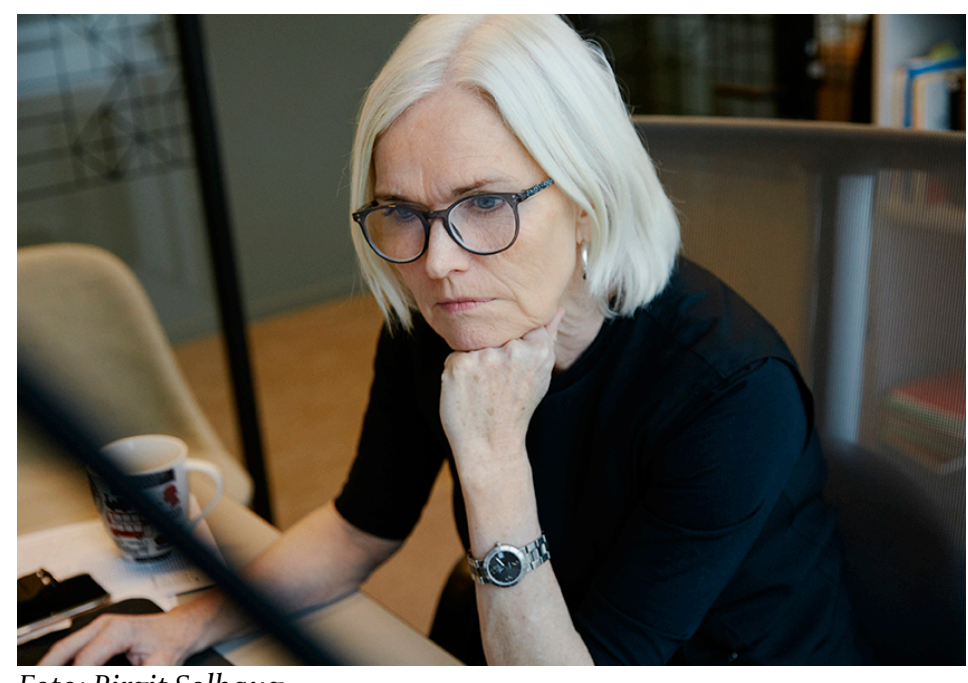

Foto: Birgit Solhaug

Hun fortsetter litt lattermildt:

- Underveis i livet forandrer vi oss. Nå har jeg andre interesser enn da jeg studerte.

Sosiologer kan brukes til mye, så jeg er veldig fornøyd med yrkesvalget mitt. En sosiologs viktigste verktøy er evnen til å observere andre. I mitt tilfelle tror jeg at jeg kan vise legene forhold om dem selv de ikke selv ser. Hvor går grensen for hva de faktisk har kunnskap om? Hvorfor virker leger så autoritetstro innad i eget fag?

Det er godt dokumentert at det er stor sosial ulikhet i helse, også i et land som Norge

Berit forteller at hun i mange år har jobbet tett sammen med helseøkonomer.

- Som forsker kan jeg være et sted mellom helsefagarbeiderne, byråkratene og helseøkonomene. Det er et godt utsiktspunkt: Jeg får innsikt innenfra, men beholder posisjonen til å se ting utenfra. Jeg har stor tro på at profesjonene selv vet hva som skal til for å lage et godt helsevesen. Hun påpeker at helseøkonomenes perspektiv også er nyttig, ikke minst fra et etisk perspektiv.

- Men økonomene kan ha et nokså snevert syn på målet med helsevesenet. Slik jeg ser det, har helseøkonomiske perspektiver bidratt til et uforholdsmessig sterkt fokus på kvantitet, for eksempel antall konsultasjoner eller utskrivninger. Men er det gode mål for helseforbedring? spør hun.

Hun problematiserer ytterligere: 
- Hvem skal legene bruke kort eller lang tid på? Hun svarer seg selv:

- Teknisk effektivitet blir fort feil, man ser på input og ikke på output. Man må også måle kvaliteten på arbeidet som utføres.

\section{Sosial ulikhet}

Dette bringer oss over på en annen problemstilling Berit Bringedal er opptatt av, nemlig hvordan sosial ulikhet kan sementeres i helsevesenet.

- Det er godt dokumentert at det er stor sosial ulikhet i helse, også i land som Norge. Selv om de viktigste årsakene til denne ulikheten ligger utenfor helsevesenet, slik som utdanning og arbeid, kan helsetjenesten bidra til å opprettholde, redusere eller forsterke ulikheten. Likebehandling kan bety at alle skal behandles likt, men det kan også bety at pasienter behandles ulikt for å realisere like resultat.

Hva som er rettferdig og moralsk riktig, er like viktig som hva som er medisinsk nyttig

Hun slår fast:-Selvsagt påvirkes behandlingen av sosiale og kulturelle forhold. Det som skjer på legekontoret, er også et produkt av slike mekanismer. Et eksempel er hvilke diagnoser pasientene får. Diagnoser er ikke objektive sannheter, de skapes i møtet mellom pasient og lege. I en studie av fordelingen av diffuse muskel- og skjelettdiagnoser versus diffuse psykiatriske diagnoser fant vi at høy utdanning øker sannsynligheten for en psykiatridiagnose. Å jobbe i industrien reduserer denne sannsynligheten. En høyt utdannet helsearbeider har så å si aldri en diffus muskel- og skjelettsykdom, mens en ufaglært industriarbeider ikke har en depresjon, for eksempel. Dette illustrerer at sosiale og kulturelle faktorer påvirker det som skjer i helsevesenet, noe som igjen kan bety sementering av sosial ulikhet. Legene er egentlig forpliktet til å ikke la seg påvirke av kjønn, rase og andre sosiale faktorer, men jeg tror det er viktig å erkjenne at de faktisk gjør det. Skjulte sosiale mekanismer styrer mer enn det som kommer fram i dagslyset.

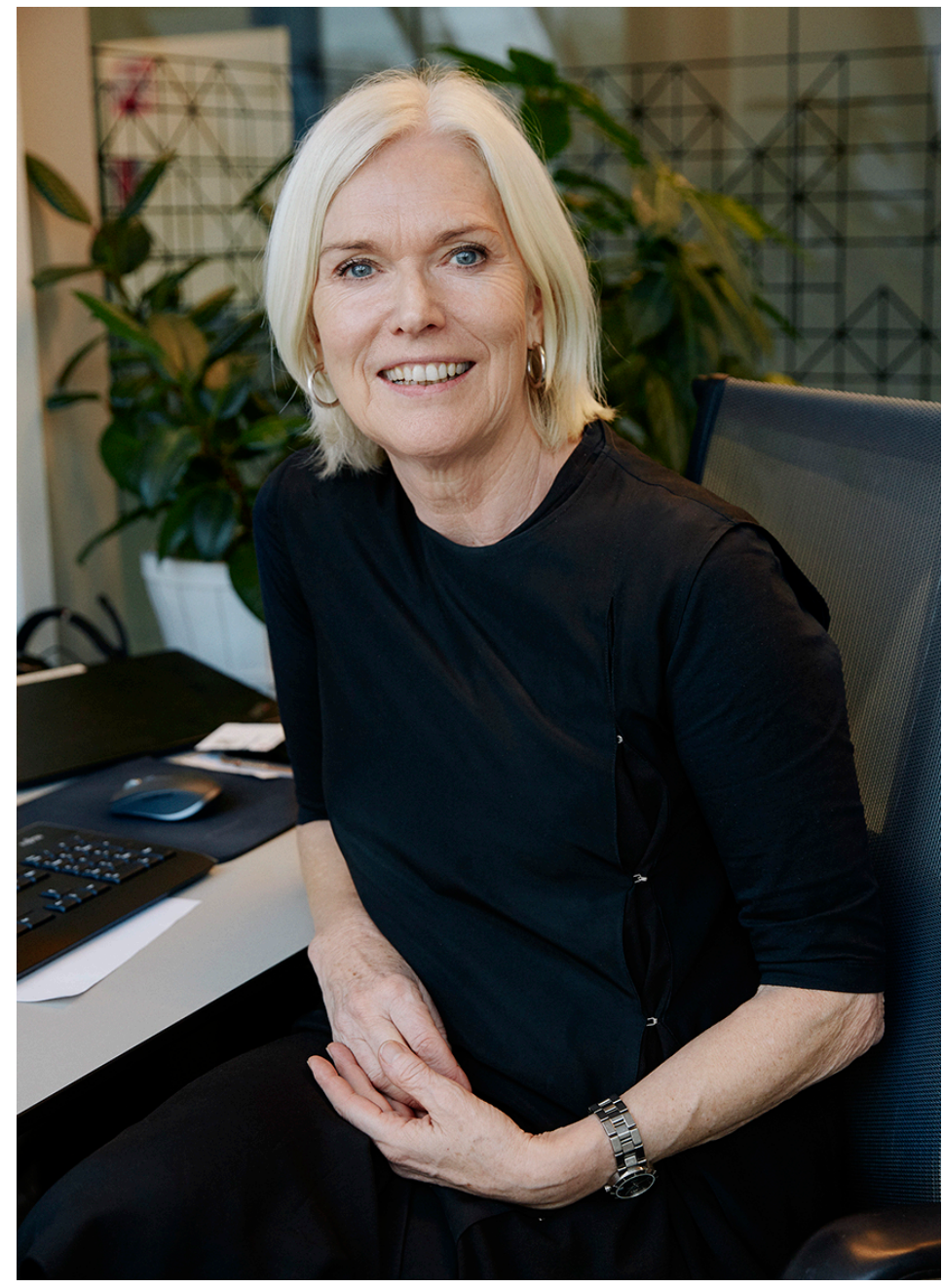




\section{Prioritering}

Berit Bringedals doktorgradsarbeid handlet om prioritering og fordelingsrettferdighet $\mathrm{i}$ helsevesenet. Hun ble derfor utfordret av Nytt Norsk Tidsskrift til å kommentere prioriteringsutvalgets innstilling da de avgav sin rapport i 2014. Deretter skrev hun like godt en kronikk i Dagens Næringsliv om hva helsevesenet bør si nei til.

- Det var mye bra i prioriteringsutvalgets innstilling, men en del analyser fra helseøkonomene synes jeg gikk for langt. Selv om alle leger må forstå at vi må regne på nytte og kostnader, kan ikke det være det eneste fokuset vi har.

Hun fortsetter: - For øvrig synes jeg legene sier for lite nei. Det er så mye man kunne sluttet med uten at det ville fått noen konsekvenser for folkehelsen. Når man regner på gevinsten av mammografiscreening i forhold til ressursbruken, er det klart at man kommer negativt ut. Jeg mener også at gravide selv kan betale for ultralydundersøkelsen i 18.-20. svangerskapsuke. Den er egentlig bare et familieportrett. Ingen har påvist at denne undersøkelsen reduserer sykelighet og dødelighet.

Det er en hårfin balanse mellom det å påvirke folk til å ta fornuftige valg for egen helse samtidig som vi ikke fordømmer dem som ikke tar de rette valgene

Hun løfter frem flere andre ting som bør drøftes, bl.a. blodtrykksgrensene for medikamentell intervensjon og om staten skal betale for rituell omskjæring.

- For ikke å glemme alle de unødvendige meniskoperasjonene! Dersom legene fikk klare og entydige retningslinjer, ville det lette ubehaget med å si nei. Da kan de vise til retningslinjene.

- Du er tøff som kaster deg inn i tunge, medisinskfaglige kontroverser ...

- Jeg ser ikke på dette som rent medisinskfaglige debatter. Når det gjelder fordeling av helsetjenestens knappe ressurser bør også ikke-medisinere lese seg til hva forskningen viser, trekke sine slutninger og delta i diskusjonene.

\section{Pasientens ansvar}

Hun ivrer etter å fortelle om forskningen hun holder på med for tiden.

- Vi forsker på legers tanker om pasientenes eget ansvar for å bidra til bedre helse og om det skal ha betydning for helsehjelpprioriteringen. Dette er interessant, bryter hun ut og spør:

- Skal en som drikker for mye alkohol, settes lenger bak i levertransplantasjonskøen enn en pasient som har leversvikt på grunn av uforskyldt sykdom? Eller skal en med medfødt lungesykdom få høyere prioritet enn en som har røykerelatert lungesykdom?

Hun påpeker at i henhold til norsk lov og legeetikken er det bare pasientens behov for helsehjelp som skal vektlegges, ikke årsakene til behovet. 


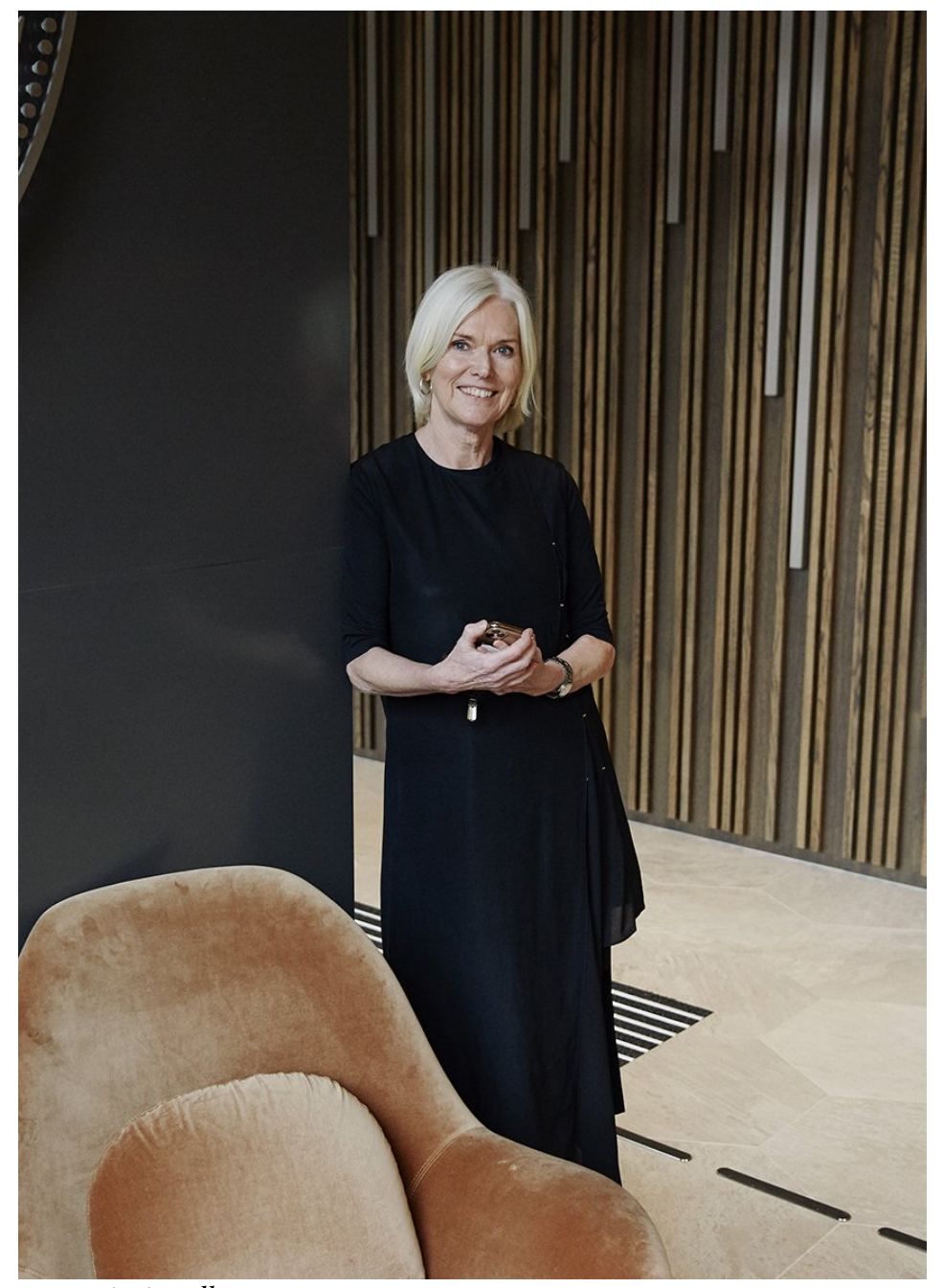

Foto: Birgit Solhaug

- Et særlig interessant spørsmål er om den norske satsingen på å styrke helseøkonomifeltet har bidratt til at legene er mer opptatt av effektiv bruk av ressursene. Sett fra et rettferdighetsperspektiv kan det absolutt være en fordel at legene også er opptatt av å bruke ressurser der de bidrar til mest mulig helseforbedring, men det bør jo kobles til en tilsvarende sterk oppmerksomhet på hva som er riktig å gjøre. Prioriteringer i helsetjenesten handler like mye om å ta vare på hverandre, barmhjertighet, verdighet og respekt som effektiv fordeling av ressurser, sier hun og utdyper:

- Trolig har leger lite tid og rom for slike diskusjoner, men spørsmål om hva som er rettferdig og moralsk riktig, er like viktig som hva som er medisinsk nyttig. Å ha plass til slike diskusjoner bidrar til å nyansere og klargjøre hvilke moralske valg som ligger til grunn for de beslutningene legene tar.

Bringedal påpeker at dette henger nøye sammen med sosial ulikhet.

- Mange av livsstilsfaktorene som øker risiko for sykdom, slik som røyking og overvekt, er mer utbredt blant folk med lavere utdanning. Nedprioritering av disse pasientene vil dermed innebære $ø$ kt sosial ulikhet $\mathrm{i}$ helse.

Hun trekker fram risikofaktorer som er vanlige blant folk med høyere utdanning, slik som idrettsskader.

- Det er ikke så vanlig å inkludere disse blant livsstilsfaktorer som bør føre til lavere prioritet. Kanskje fordi det er lettere å dømme røyking, alkoholmisbruk og overvekt som uforsvarlig eller umoralsk? spør hun retorisk og avslutter:

- Det er en hårfin balanse mellom det å påvirke folk til å ta fornuftige valg for egen helse samtidig som vi ikke fordømmer dem som ikke tar de rette valgene. Det ligger en sårbarhet i dette som kan være vanskelig å forstå. Her ligger kanskje mye av essensen i det å være en 
god lege.

Publisert: 11. januar 2021. Tidsskr Nor Legeforen. DOI: 10.4045/tidsskr.20.0847

(C) Tidsskrift for Den norske legeforening 2020. Lastet ned fra tidsskriftet.no 